\title{
Introduction to the Principles of $\delta^{18} \mathrm{O}, \delta^{13} \mathrm{C}$, and ${ }^{87} \mathrm{Sr} /{ }^{86} \mathrm{Sr}$ in the Palaeosciences.
}

\author{
Jack Thomas Rhodes Wilkin \\ Camborne School of Mines. College of Engineering, Mathematics and Physical Sciences. \\ University of Exeter. Penryn Campus. Penryn. Cornwall. TR10 9EZ
}

Keywords: $\delta^{18} \mathrm{O}, \delta^{13} \mathrm{C},{ }^{87} \mathrm{Sr} /{ }^{86} \mathrm{Sr}$, Palaeontology, Geochemistry.

This article has been submitted to the journal Frontiers in Earth Science

The stable isotopes of oxygen $(\mathrm{O})$, carbon $(\mathrm{C})$, strontium $(\mathrm{Sr})$, hydrogen $(\mathrm{H})$, and nitrogen $(\mathrm{N})$ have all been utilised for great effect in palaeoclimate, palaeoecological and palaeobiological studies. Of these, $\mathrm{O}$ and $\mathrm{C}$ have been by far the most important and, in many types of study, their use has become routine in universities and research institutions around the world. Stable isotopes provide quantitative data about palaeotemperatures, metabolic rates, food webs, palaeosalinity, palaeoprecipitation and evaporation rates as well as glacial ice volumes, production and burial of organic carbon, and other processes related to palaeoclimatic/biological/ecological change. Except for Sr, all the previously mentioned isotopes $(\mathrm{O}, \mathrm{C}, \mathrm{H}$, and $\mathrm{N})$ directly record paleoclimatic, biological and palaeoecological processes. Conversely, $\mathrm{Sr}$ reflects the composition of rocks at the Earth's surface, and its values reflect on the climate indirectly as it is a proxy for global weathering rates and seafloor spreading. This review will only be focusing on three isotopes commonly deployed by palaeoresearchers: carbon, oxygen, and strontium. 


\section{Introduction}

The first evidence for multiple isotopes for stable elements was found by Sir Joseph John Thomson (Thomson, 1910, 1912). The term isotope was first coined by English radiochemist Fredrick Soddy (1913) to distinguish chemical elements with different atomic masses, different numbers of neutrons, but occupy the same position of the periodic table, same numbers of protons and electrons. The term isotope is derived from iso meaning equal and the Greek topos meaning place in reference to the same placement in the periodic table (Ellam, 2016).

Concentrations of isotopic species are represented by the relative abundance ratios of the heavy to the light isotopes in each sample to the ratio of a given standard. The values of the $\delta$ can be either positive, showing an enrichment of the heavier isotopes relative to the standard, or negative, showing depletion of the heavier isotopes relative to the standard (Ellam, 2016).

There are two main types of isotope: radioactive isotopes and stable isotopes Radioactive isotopes, also called radionuclides, are species of the same chemical element that contains unstable nuclei and dissipate excess energy by spontaneity emitting radiation in the form of alpha $(\alpha)$ beta $(\beta)$ and gamma $(\gamma)$ rays. Unlike stable isotopes, radioactive isotopes have different isotopic mass by having differing numbers of electrons in their electron shells rather than a different number of neutrons in the nucleus. Thus, this extra electron will give the isotope a negative change, when the electron is released the isotope will drop down an energy level becoming a different atom in a process called radioactive decay (Faure and Mensing, 2005; Ellam, 2016). This phenomenon, whereby one radioactive substance transforms from one element to another, was first observed by Rutherford and Soddy (1902).

In contrast stable isotopes as species of the same element that have differing numbers of neutron and do not decay over time. Stable isotopes are of interest to palaeoclimatologists as their preserve the original geochemical signatures unless acted upon by external forces such as diagenetic alternation, from the past (Faure and Mensing, 2005; Ellam, 2016). There are several stable isotopes that are commonly used by researchers to reconstruct past conditions such as strontium which can be used in reconstructing sea-level change (Jiang et al., 2001; van der Meer et al., 2017) and variations Mid-ocean ridge active (Jones et al., 1994) while boron which is an ocean $\mathrm{pH}$ proxy in foraminifera (Foster and Rae, 2016). 
Isotopic palaeontology is a sub-discipline of palaeontology that uses the geochemical composition of fossil remains of organisms to make inferences about the physical surroundings of growth of the organisms (especially temperature), diets and palaeoclimates (Wefer and Berger, 1991; Hudson and Marshall, 1997). Most research in this field revolves around marine organisms -especially unicellular foraminifera from the K-Pg extinction onwards (e.g. Zachos et al., 2001; Austin and James, 2008) and belemnites for most of the Mesozoic ( e.g. Sælen et al., 1996; Prince and Sellwood, 1997; Wierzbowski and Joachimski, 2007, 2009; Wilmsen and Niebuhr, 2017) - to work out past ocean chemistry and, therefore, ancient climates.

\section{$\delta^{18} \mathrm{O}$}

Oxygen (O), by mass, is Earth's most abundant element, forming the most common components of the hydrosphere, biosphere and lithosphere (Faure and Mensing, 2005; Pederzani and Britton, 2018). Oxygen naturally occurs, with decreasing abundance, as one of three stable isotopes: ${ }^{16} \mathrm{O}(99.755 \%),{ }^{18} \mathrm{O}(0.206 \%)$ and ${ }^{17} \mathrm{O}(0.039 \%)$ (Schoeller, 1999; Pederzani and Britton, 2018)

Oxygen-isotopes has a long history in the palaeosciences since Urey (1947) first suggested that $\delta^{18} \mathrm{O}$ from fossil calcite could be used to estimate past temperatures. Temperature is the most primary representation of the state of the climate, and the temperature of the oceans is critical as the oceans are the single most crucial component of the Earth's climate system (Bigg, 2003). Isotopes and trace elements can be used to estimate ancient temperatures. Isotopic ratios can be taken from ice cores (e.g. Robin, 1977; Siegenthaler et al., 1988; Hendricks et al., 2000), sediment samples (e.g. Jenkyns and Clayton, 1986; Wilmsen and Niebuhr, 2017) and fossil shells and bones. Oxygen isotope analyses of marine carbonate fossils could substantiate the modelled palaeoclimate evolution by providing information on oceanic palaeotemperatures. Elements used for calculating palaeotemperatures are called palaeothermometers.

The following equation is used to calculate the $\delta$-value of oxygen:

$$
\delta^{18} \mathrm{O}=\left(\frac{\left(\frac{18}{\left.\frac{18}{16}\right)_{\text {Sample }}}\right.}{\left(\frac{18 .}{16}\right)_{\text {standard }}}-1\right) * 1000
$$

The $\delta^{18} \mathrm{O}$ and $\delta^{13} \mathrm{C}$ values have concentration units of per thousand, or 'per mil' (\%o) relative to the standard. For example, a $\delta^{18} \mathrm{O}$ value of $1.0 \%$ means that the sample has an ${ }^{18} \mathrm{O} /{ }^{16} \mathrm{O}$ ratio 
that is $0.1 \%$ greater than the standard, or a $\delta^{13} \mathrm{C}$ value of $-25 \%$ means that the sample has a ${ }^{13} \mathrm{C} /{ }^{12} \mathrm{C}$ ratio that is $2.5 \%$ lower than that of the standard (Ravelo and Hillaire-Marcel, 2007).

Many marine organisms are thought to have secreted their calcite shells in isotopic equilibrium with seawater; consequently, their $\delta^{18} \mathrm{O}$ values are presumed to be a reliable palaeothermometer (e.g. Sælen et al., 1996; Prince and Sellwood, 1997; Wierzbowski and Joachimski, 2007, 2009). Temperature changes related to migrations and seasonal variations can also be detected using oxygen isotopes (Rexfort and Mutterlose, 2006, 2009), hence the importance of acquiring multiple samples from the same specimen. The first use of oxygen as a paleothermometer was conducted by Urey et al. (1951) based on belemnites from the United States, United Kingdom and Denmark.

Organisms with hard parts made of calcium carbonate $\left(\mathrm{CaCO}_{3}\right)$ and phosphates combine dissolved inorganic carbon in the form of bicarbonate $\left(\mathrm{HCO}_{3}^{-}\right)$from the water to make their shells, skeletons, and tests in a process called marine biogenic calcification using the following equation (Zondervan et al., 2001):

$\mathrm{Ca}^{2+}{ }_{(\mathrm{aq})}+2 \mathrm{HCO}^{-}{ }_{3(\mathrm{aq})} \rightarrow \mathrm{CaCO}_{3(\mathrm{~s})}+\mathrm{CO}_{2}+\mathrm{H}_{2} \mathrm{O}$.

To calculate palaeotemperatures from $\delta^{18} \mathrm{O}$ values, several different equations can be used:

- Anderson and Arthur (1983): $\mathrm{T}\left({ }^{\circ} \mathrm{C}\right)=16.0-4.14(\delta \mathrm{c}-\delta \mathrm{w})+0.13(\delta \mathrm{c}-\delta \mathrm{w})^{2}$

- $\quad$ Epstein and Mayeda (1953): $\mathrm{T}\left({ }^{\circ} \mathrm{C}\right)=16.5-4.3(\delta \mathrm{c}-\delta \mathrm{w})+0.14(\delta \mathrm{c}-\delta \mathrm{w})^{2}$

- Sharpe (2007): T $\left({ }^{\circ} \mathrm{C}\right)=15.75-4.3(\delta \mathrm{c}-\delta \mathrm{w})+0.14(\delta \mathrm{c}-\delta \mathrm{w})^{2}$

Following advice from Dr Clemens Ullman of the Camborne School and Mines (personal communication, February 25, 2019) the Epstein equation was not used in the final palaeotemperature reconstructions for the Bathonian-Callovian Boundary as the formula was incorrect due to lack of understanding regarding how water and carbonates fractionate during mass spectrometry in the 1950s thus Epstein and Mayeda (1953) equation are seldom used, and authors more commonly employ Anderson and Arthur (1983) or other more recent equations.

$\mathrm{A} \delta^{18} \mathrm{O}$ of seawater of $-1 \%$ SMOW is generally used during greenhouse conditions, to account for the absence of ice-sheets (Shackleton and Kennett, 1975). Therefore, when calculating palaeotemperatures for much of the geological record, 1 needs to be added on for $\delta^{18} \mathrm{O}$ values to account for the negative SMOW. 
The use of oxygen isotopes as a method to provide a geological thermometer has limitations that must be considered. Firstly, the isotopic results, although calculated in degrees Celsius, should be thought of as "isotopic temperatures" rather than "palaeotemperatures" (Stevens and Clayton, 1971) providing relative temperatures rather than absolute results. Individual temperatures should, therefore, not be interpreted too literally. Lowenstam and Epstein (1954, p. 209) commented: "Our emphasis . . . will be on determining trends in temperature, both geographical and chronological, rather than the determination of absolutely precise temperatures."

A number of processes must be considered before interpreting oxygen-isotope data for palaeoclimatic changes (Parrish, 1998):

- Fractionation within the atmosphere and during crystallisation

- Changes in the original isotopic composition of the water

- Biological fractionation

- Diagenesis

Fractionation of oxygen-isotopes occurs within the atmosphere when water is evaporated, transported and finally precipitated. Fractionation happens on both local and global scales (see Yurtsever, 1975).

Because light water $\left(\mathrm{H}_{2}{ }^{16} \mathrm{O}\right)$ preferentially evaporates, saline waters tend to have higher $\delta^{18} \mathrm{O}$ values. Elevated salinities have the same effect on isotope signatures as temperatures, that is lower $\delta^{18} \mathrm{O}$ values. Because saline waters can be warm, produced by evaporation at high temperature, the effects of temperature and salinity on isotopic composition work against each other. Thus, determining the relative effects of salinity and temperature can be difficult (see Tourtelot and Rye, 1969). It should be noted, however, that many researchers ignore salinity as a variable as its effects are relatively small (Parrish, 1998).

Isotopic measurements taken from ice cores measure the $\mathrm{aD}$ and $\mathrm{a}^{18} \mathrm{O}$ ratios. Isotopes recovered from ice caps have lighter than $\mathrm{aD}$ and $\mathrm{d}^{18} \mathrm{O}$ ratios ocean water due to path fractionation. Fractionation occurs when heavier isotopes are "rained out" as air pockets move over land, condenses, and the water is lost during precipitation with heavier isotopes being depleted at a faster rate than lighter ones so by the time precipitate over high latitudes there is a disproportionately high ratio of $\mathrm{O}^{16}$ (Gat, 1996; Werner et al., 2018; Fig 1). 


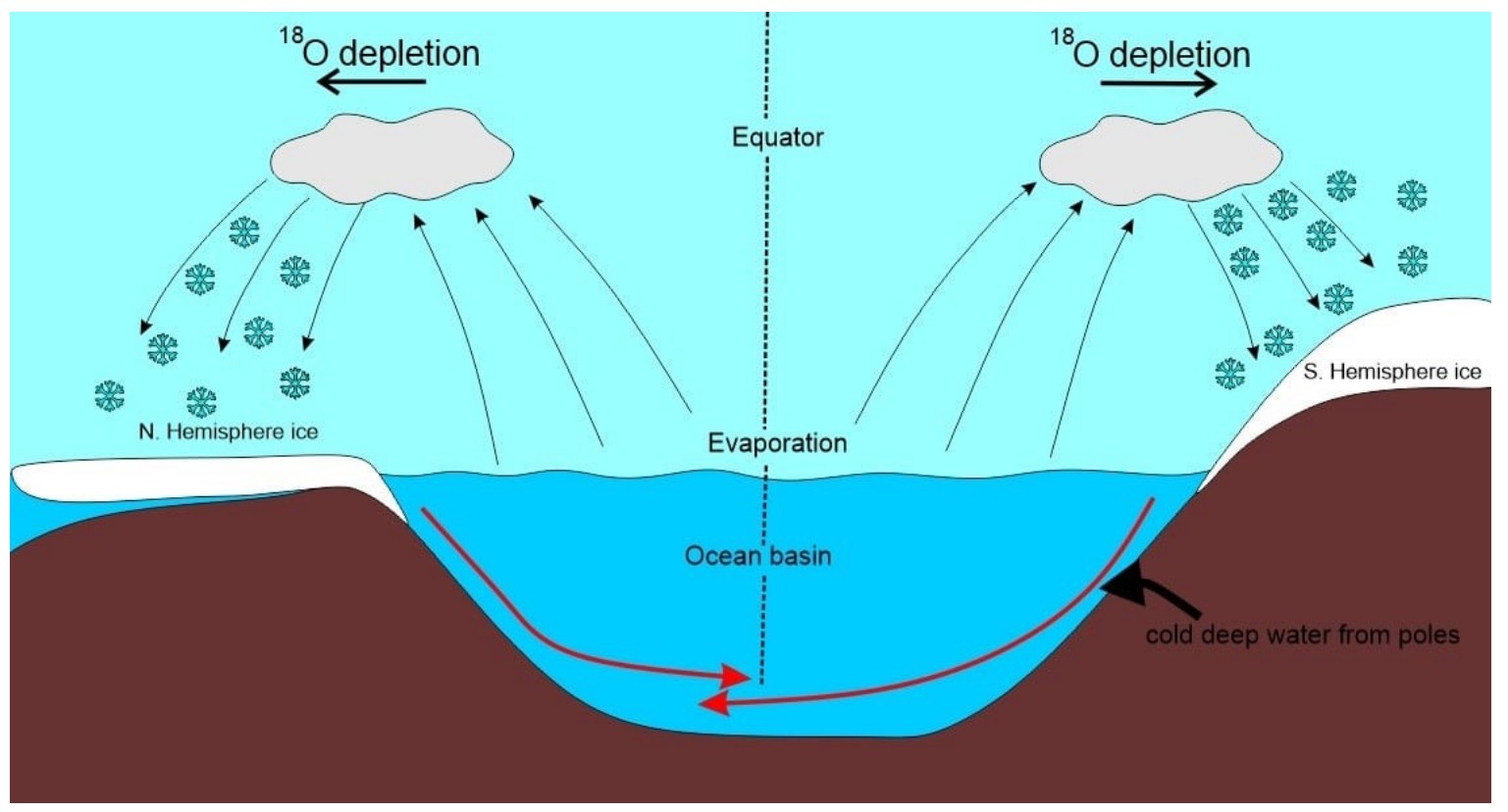

Figure 1: path fractionation of oxygen isotopes. Taken from Wilkin (2020)

In the high latitude, surface waters tend to have lower $\delta^{18} \mathrm{O}$ values than deeper waters. These low values are due to marine waters becoming contaminated with meltwater from ice fields, thus returning the isotopically lighter ${ }^{16} \mathrm{O}$ to the oceans, while the marine waters of high salinity were richest in ${ }^{18} \mathrm{O}$. The observed relation between ${ }^{18} \mathrm{O}$ content and salinity of the oceanic waters can be explained by process of multiple-stage distillation which produces a continuous loss of freshwater to the ice regions from the surface waters of the warm oceans. The lower salinities of cold ocean currents, such as the Alaskan and Californian currents, are due primarily to mixing with meltwater from cold regions. The effect of glaciation upon the isotopic method of measuring paleotemperatures is discussed by Epstein and Mayeda (1953) with a more recent discussion provided by

Diagenesis is the term that encompasses all the chemical changes that occur to a fossil after burial. Diagenetic processes include dissolution, recrystallisation and replacement by other minerals: all these processes can affect the isotopic ratios in a given substance (e.g. Sælen, 1989; Blanchet et al., 2012; Ullmann and Korte, 2015). An understanding of diagenetic processes is fundamentally crucial because meaningful data can only be collected from unaltered material - that is containing the original atoms in the bone phosphate that was there when the animal was still alive.

Diagenesis tends to homogenise seasonal signals, as it resets the original isotope values to those of the surrounding sediment and pore fluids, and therefore alter and in extreme cases can 
completely erase any geochemical data (Ullmann and Korte, 2015). Therefore, researchers must assess the degree of alteration before continuing a geochemical analysis to ensure the data they collect is reliable. The following list is adapted from Owocki et al. (2019).

- Comparison of the geochemical and isotopic composition of skeletal tissues with various levels of preservation potential, e.g. enamel, dentine and bone.

- Analysis of the preservation of expected isotopic differences between related taxa with known ecological or physiological differences and of seasonal cycles.

- Analysis of crystalline microstructure and composition as prerequisites to the preservation of original isotope values as recrystallisation deforms crystals in the fossils and alters their chemistry.

- Precipitation of secondary minerals through water-fossil interactions can result in elemental enrichment of $\mathrm{Fe}$ and $\mathrm{Mn}$, as these replace $\mathrm{Ca}$. Therefore, researchers apply "diagenetic cut-off points" to samples with specimens with a $\mathrm{Fe} / \mathrm{Ca}$ or $\mathrm{Mn} / \mathrm{Ca}$ ratio over a given amount being omitted from further study (see Ullmann and Korte, 2015 for a review of diagenetic screening techniques in belemnites).

If the $\delta^{18} \mathrm{O}$ of the water and a bone is known, it is possible to calculate the body temperature of extinct vertebrates using the following equation (Showers et al., 2002):

$$
\mathrm{T}^{\circ} \mathrm{C}=111.4-4.3\left(\delta^{18} \mathrm{O}_{\text {phosphate }} \delta^{18} \mathrm{O}_{\text {water }}\right)^{*} 1000 .
$$

Oxygen isotopes taken from dinosaur bones show little variation, implying a near-constant body temperature. For example, Amiot et al. (2006) analysed Cretaceous dinosaurs from high latitudes of different taxonomic groups. They found that dinosaurs maintained a constant body temperature of $36-38^{\circ} \mathrm{C}$, a range consistent with living endotherms, regardless of ambient temperature. This conclusion implies that high metabolic rates were commonplace amongst Cretaceous dinosaurs. The study tested the $\delta^{18} \mathrm{O}_{\text {water }}$ and $\delta^{18} \mathrm{O}_{\text {phosphate }}$ of sauropods, theropods, ornithopods and ceratopsians. Such a similar thermophysiology and endothermy was a common trait, synapomorphy, shared by all dinosaurs. 
$\delta^{13} \mathrm{C}$

Carbon (C) is the sixth most abundant element in the solar system (Anders and Ebihara, 1982) and plays an important role in the geochemical processes that occurs near the Earth's surface, the biosphere, atmosphere, hydrosphere and in the lithosphere (in sedimentary, metamorphic and igneous rocks) (Faure and Mensing, 2005).

The isotopic composition of $\mathrm{C}$ is expressed by the $\delta^{13} \mathrm{C}$ values, defined as:

$$
\delta^{13} \mathrm{C}=\left(\frac{\left(\frac{{ }^{13} \mathrm{C}}{{ }^{12} \mathrm{C}}\right)_{\text {Sample }}}{\left(\frac{{ }^{13} \mathrm{C}}{{ }^{12} \mathrm{C}}\right)_{\text {standard }}}-1\right) * 1000
$$

where the standard is the PDB (Pee-Dee belemnite). When the $\delta^{13} \mathrm{C}$ values are positive, the $\mathrm{C}$ is enriched with ${ }^{13} \mathrm{C}$ relative to the standard, while negative $\delta^{13} \mathrm{C}$ values imply depletion in ${ }^{13} \mathrm{C}$ relative to the standard. The $\delta^{13} \mathrm{C}$ values in marine carbonates are close to zero because the P.B.D. standard itself is a marine carbonate (Catling and Kasting, 2017).

The isotopic geochemistry of $\mathrm{C}$ has been summarised by several authors (e.g. Farmer and Baxer, 1976; Deines, 1980; Hazen, 2018) and by Faure and Mensing (2005, pp.753-802).

The fractionation factor for $\mathrm{C}$ isotopes is defined as:

$$
\alpha \frac{a}{b}\left(C^{13}\right)=\frac{R_{a}}{R_{b}}
$$

Where $a$ and $b$ are C-bearing compounds in isotopic equilibrium with a certain temperature and $R$ is the isotopic ${ }^{13} \mathrm{C} /{ }^{12} \mathrm{C}$ ratio. The isotopic composition of $\mathrm{C}$ is biogenic carbonates and organics, however, are an unreliable palaeotemperature proxy as these kinds of compounds do not achieve isotopic equilibrium with major $\mathrm{C}$ reservoirs. In organic matter, it is because plants discriminate against ${ }^{13} \mathrm{C}$ during photosynthesis in favour of the isotopically lighter ${ }^{12} \mathrm{C}$ and this negative $\delta^{13} \mathrm{C}$ bias is passed along to herbivorous and carnivorous animals (O'Leary, 1988). It is possible, alongside $\delta^{18} \mathrm{O}$ and $\delta^{15} \mathrm{~N}$, to reconstruct food webs and diets on animals (e.g. DeNiro and Epstein, 1978; Post, 2002; Hopkins and Ferguson, 2012; Parng et al., 2014) and humans (e.g. Hakenbeck et al., 2010; Webb et al., 2013; Lamb et al., 2014) using stable isotope ratios.

One recently published example that shows the use of carbon-isotopes in establishing predatorprey relationships is Owocki et al. (2019). The authors analysed oxygen and carbon isotopes 
from tooth enamel of Tarbosaurus bataar, a close relative of Tyrannosaurus from Mongolia, and a sauropod (Nemegtosaurus) and hadrosaurs (Barsboldia and Saurolophus) from the Nemegt Formation (Maastrichtian, Upper Cretaceous). The $\delta^{13} \mathrm{C}$ values of herbivorous dinosaur tooth enamel suggested a closed canopy forest of Araucaria, which is supported by petrified wood found in multiple localities throughout the Nemegt Formation. By comparing the $\delta^{13} \mathrm{C}$ signals of the different dinosaur fauna, Owocki et al. (2019) concluded that Tarbosaurus was the apex predator in its organism. The isotopes show that the tarbosaurs were feeding on giant sauropods though it is possible, however, that were scavenging sauropod carcasses (see Holtz, 2008 for an in-depth review of the tyrannosaur scavenger hypothesis).

The method employed by Owocki et al. (2019) works because different plant groups have different $\delta^{13} \mathrm{C}$ values due to the way they take in carbon during photosynthesis - a process called fractionation. As carbon moves through food webs, it slowly becomes enriched (therefore the $\delta^{13} \mathrm{C}$ values increases), so the values need to be adjusted due to a process called trophic fractionation. A study by Wings et al. (2014) compared $\delta^{13} \mathrm{C}$ from theropod and sauropod enamel from the Jurassic Qigu and Shishugou formations of western China and found that theropod $\delta^{13} \mathrm{C}$ was $\sim 1.7 \%$ lower than the contemporaneous herbivores. Using Wings et al. (2014) results, Owocki et al. (2019) then adjusted their tarbosaur results accordingly. The researchers found that the carbon-isotope values overlapped both hadrosaur and sauropod $\delta^{13} \mathrm{C}$ values providing clear evidence of a predator-prey relationship and carbon transfer (Fig 2). The results in both studies are consistent with what has been found in modern mammalian predators who have about 1.3-2.6\% lower $\delta^{13} \mathrm{C}$ values in their enamel than their prey (Bocherens et al., 1995).

Isotopic measurements can also be taken from the teeth of grazing mammals (e.g. Cerling et al., 1997; Clementz, 2012). Those eating modern grasses have a $\mathrm{C}_{4}$ signal and those eating more primitive grasses have a $\mathrm{C}_{3}$ signal. $\mathrm{C}_{4}$ grasses are adapted to arid environments whilst $\mathrm{C}_{3}$ grasses indicate cold conditions. There was a major climate shift around 5 to 7 million years ago when the main grass type changed from predominantly $\mathrm{C}_{3}$ to $\mathrm{C}_{4}$. This shift is linked to the cooling and drying of the climate in the Late Miocene and the start of the Ice Age. The reasons for this change remain unclear but is thought to be related to changes in atmospheric $\mathrm{CO}_{2}$ concentrations (Wallace, 2004). 


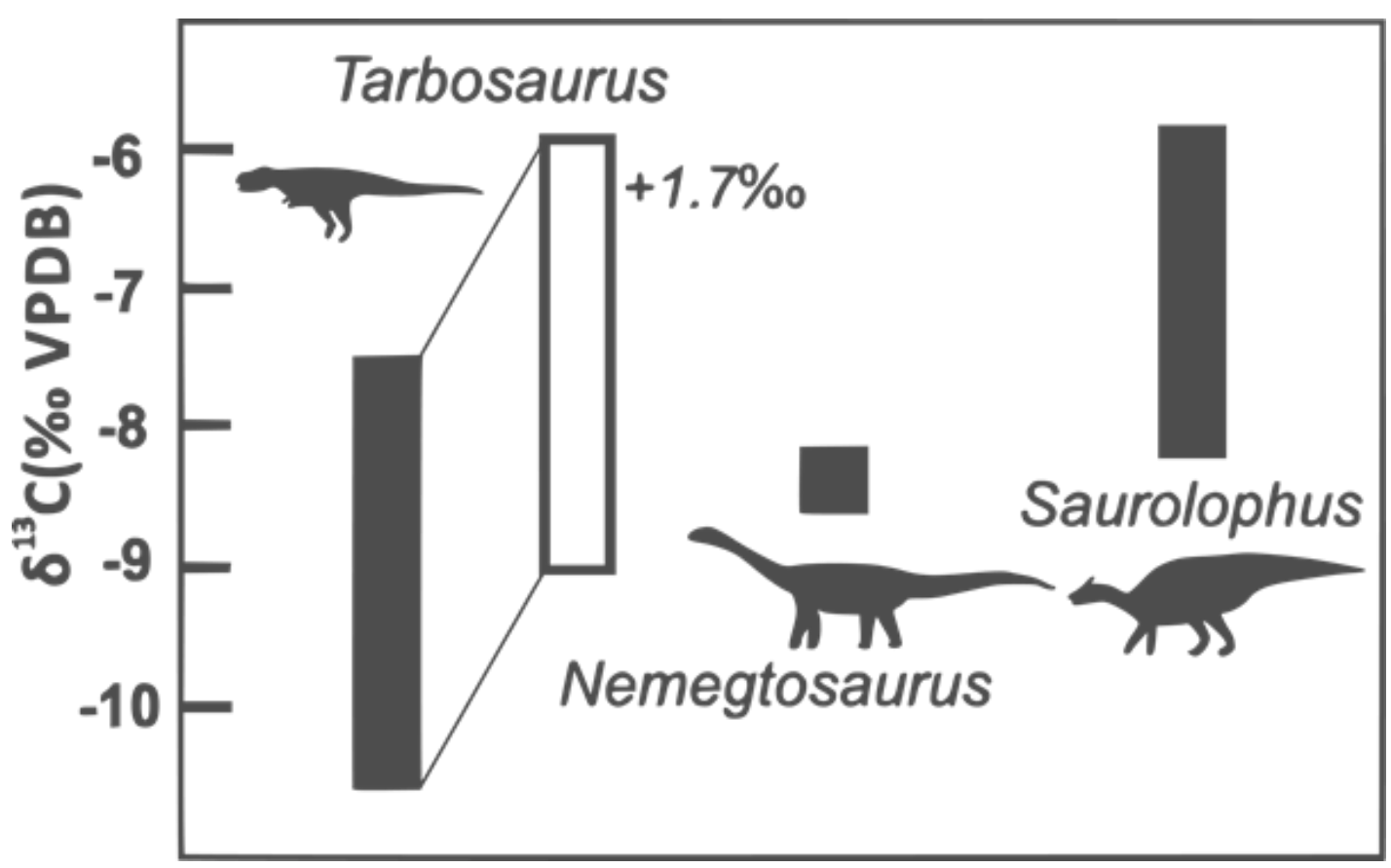

Figure 2: $\delta^{13} \mathrm{C}$ values from tooth enamel of various dinosaurs analysed by Owocki et al. (2019). To account for trophic fractionation, the Tarbosaurus data was adjusted by $\sim 1.7 \%$ following Wings et al. (2014). Redrawn from Owocki et al. (2019).

When an increase in nutrients stimulates biomass production in the surface of the water column, the difference in $\delta^{13} \mathrm{C}$ values between pelagic and benthic species increases. The loss of $\mathrm{C}$ from the surface of the water is compensated by the addition of $\mathrm{CO}_{2}$ from the atmosphere (Shackleton et al., 1983) and thus decreasing atmospheric $\mathrm{CO}_{2}$ concentrations which can result is the cooling of the global average temperature. Such a scenario leads to a positive feedback loop in the global climate system as a decrease in water surface temperature increases the solubility of $\mathrm{CO}_{2}$ in the oceans which causes additional loss of $\mathrm{CO}_{2}$ in the atmosphere further decreasing global temperatures.

Throughout geological time, there have been numerous negative carbon isotope excursions (nCIEs) which are interpreted as episodes of massive carbon release. The study of such events is crucial as it helps connect past carbon cycling and climate variability. The study of nCIEs is important as it parallels current global warming trends. As of 2019, anthropogenic fossil fuel emissions have already caused the isotopic composition of atmospheric $\mathrm{CO}_{2}\left(\delta^{13} \mathrm{C}_{\mathrm{CO}}\right)$ has already declined by $\sim 1.5 \%$ (Vervoort et al., 2019) in the Suess Effect first described by Suess (1955). According to Norris et al. (2013), current anthropogenic warming will be recorded as a nCIE in future sedimentological records. Multiple nCIEs in the geological record may be associated with coeval increases in average global temperatures, ocean acidification and even 
extinction events (e.g. Kaiho et al.,2009; Erba et al., 2010; Stanley, 2010; Bartlett et al., 2018; Elling et al., 2019) and these effects are being observed in the early twenty-first century (e.g. Thomas et al., 2004; Hansen et al., 2006; Pandolfi et al., 2011).

One widely studied example of such an event is the Toarcian Ocean Anoxic Event, a major ocean redox perturbation (Jenkyns, 1988) that occurred during the Early Jurassic epoch, c. 183 million years ago (McArthur et al., 2008). This event is characterised by wide-spread deposition of organic-rich marine shales as well as a sudden perturbation in the global carbon cycle (Hesselbo et al., 2007). This event is associated with a negative carbon excursion which implies large scale inputs of carbon into the oceans which were triggered by the release of methane gas hydrates (Hesselbo et al., 2000; Beerling et al., 2002), thermally metamorphised sedimentary organic matter, as well as global warming caused by an increase in atmospheric $\mathrm{CO}_{2}$, increased continental chemical weathering which may have been up to $530 \%$ higher than the pre-event baseline (Them II et al., 2017).

The increased which then increased sediment supply due to higher weathering rates (Cohen et al., 2004; Hesselbo et al., 2007) increased productivity resulting in shallow-water anoxia creating a negative feedback loop on atmospheric $p \mathrm{CO}_{2}$ levels (Them II et al., 2017). The upsurge in marine primary productivity (Them II et al., 2017; Xu et al., 2018) led to the widespread deposition of organic-rich sediments reaching up to $20 \%$ in some localities (Jenkyns, 1988; Schouten et al., 2000; Bailey et al., 2003) and left a pronounced negative carbon isotope shift in the geological record (e.g. Jenkyns and Clayton, 1986; Schouten et al., 2000; Hesselbo et al., 2000; Hesselbo et al., 2007; McArthur et al., 2008). The increase in atmospheric $\mathrm{CO}_{2}$ led to a rise to seawater temperatures (Bailey et al., 2003). These changes in the climate resulted in a mass extinction event (Harries and Little, 1999; Wignall et al., 2005; Caruthers et al., 2013). The Toarcian turnover was a seventh largest extinction event is Earth's history (Owens and Them II, 2018).

The isotopic composition of $\mathrm{C}$ in carbonates depends on several factors as outlined by Faure and Mensing (2005, pp.764-765):

1) isotope fractionation between $\mathrm{CO}_{2}$ gas in the atmosphere and biogenic/abiogenic $\mathrm{CaCO} 3$.

2) Isotope fractionation among the aqueous carbonate species $\left(\mathrm{CO}_{2(\mathrm{aq})}, \mathrm{H}_{2} \mathrm{CO}_{3}, \mathrm{HCO}_{3}\right.$, and $\left.\mathrm{CO}_{3}{ }^{2-}\right)$ and $\mathrm{pH}-$ dependent species. 
3) Temperature of the water at the time of secretion.

4) The mineral composition of the $\mathrm{CaCO}_{3}$ - calcite or aragonite.

5) Introduction of non-atmospheric $\mathrm{CO}_{2}$ formed by oxidisation of organic matter.

6) Vital effects related to metabolic processes of organisms.

7) Alteration of $\mathrm{CaCo}_{3}$ during diagenesis (and in extreme example metamorphism) and the deposition of secondary $\mathrm{CaCO}_{3}$ in fractures/cavities from groundwater/subsurface brines.

The potential of diagenesis to alter primary $\delta^{13} \mathrm{C}$ values must be evaluated on a case by case basis (Marshall, 1992). For examples, in samples connected from outcrops (as all the material in this study were), the isotopically lighter $12 \mathrm{C}$ may have been introduced by meteoric waters thus producing more negative $\delta^{13} \mathrm{C}$ values. Meteoric water diagenesis generally also results in lowered $\delta^{18} \mathrm{O}$ values, therefore a negative correlation between $\delta^{13} \mathrm{C}$ and $\delta^{18} \mathrm{O}$ values is expected (Banner and Hanson, 1990; Knauth and Kennedy, 2009). One example of meteoric diagenesis in the geological record is reported by Fujioka et al (2019) who analysed $\delta^{13} \mathrm{C}$ and $\delta^{18} \mathrm{O}$ values from Pliocene brachiopod shells and assessed the degree of diagenetic alteration using minor element (Mn, Fe and $\mathrm{Sr}$ ) concentrations, cathodoluminescence and shell microstructure.

The depth within the water column would also have affected the $\delta^{13} \mathrm{C}$ values of biogenic calcite. Shackleton and Kennet (1975) demonstrated that pelagic foraminifera are enriched in $\delta^{13} \mathrm{C}$ relative to benthic foraminifera due to the preferential removal of ${ }^{12} \mathrm{C}$ from the surface layer of the oceans by photosynthetic organisms. The subsequent decay of organics at the ocean floor enriches deeper waters in ${ }^{12} \mathrm{C}$ and thus causes benthic species to be depleted in $13 \mathrm{C}$ compared to pelagic forms. Such a phenomenon is observed between belemnites, which are often interpreted to have been pelagic (e.g. Jeletzky, 1966; Donovan, 1977; Arkhipkin et al., 2012), and benthic bivalves. Several studies (e.g. Podlaha et al., 1998) have shown $\delta^{13} \mathrm{C}$ depletion in bivalves and enrichment in belemnites, a result consistent with Shackleton and Kennet's (1975) foraminifera.

Differences in $\delta^{13} \mathrm{C}$ can also be observed between juveniles and mature specimens of foraminifera. Such discrepancies depends on (i) distinct "vital effects", (ii) changes of habitat during the life cycle and seasonal shifts in environmental conditions, (iii) the deposition of secondary calcite in large sinking shells, and (iv) differential dissolution of shells depending on the thickness of their walls during early diagenetic processes (e.g. Lohmann, 2006). 
${ }^{87} \mathrm{Sr} /{ }^{86} \mathrm{Sr}$

Strontium (element number 38 in the periodic table) is a trace element commonly found in many minerals usually with average concentrations in the Earth's crust averaging $300 \mu \mathrm{g} / \mathrm{g}$. Sr is the 15th most abundant element on Earth, making up $0.034 \%$ of the crust (Höllriegl \& München, 2011) and is much rarer in the Earth's mantle having a concentration of approximately $30 \mu \mathrm{g} / \mathrm{g}$ (Jagoutz et al., 1979). Because it is chemical behaviour is very similar to that of calcite, having doubly changed positive ions in most natural substances, it readily substitutes for calcium in minerals (Höllriegl \& München, 2011). Sr is usually present as an impurity, replacing $\mathrm{Ca}$, with elevated concentration is mineral such as plagioclase and importantly for this work - calcite. Though it is worth noting that strontium can form its own minerals for example strontianite $\left(\mathrm{SrCO}_{3}\right)$ or celestine $\left(\mathrm{SrSO}_{4}\right)$.

Strontium has four stable isotopes are found in nature ${ }_{38}^{46} \mathrm{Sr} ;{ }_{38}^{48} \mathrm{Sr} ;{ }_{38}^{49} \mathrm{Sr}$ and ${ }_{38}^{50} \mathrm{Sr}$ first discoved by Nier (1938) - and 16 radioactive isotopes have been produced artificially. Most of the radioactive isotopes of strontium are short-lived and of little interest. The exception is strontium-90 (half-life 29.1 years), a beta-emitter that is produced as a fission fragment.

In addition to being a stable isotope, ${ }^{87} \mathrm{Sr}$ is also the radiogenic daughter isotope produced by the $\beta$-decay from the radioactive alkali metal ${ }^{87} \mathrm{Rb}$. The half-life of ${ }^{87} \mathrm{Rb}$ is $4.967(32) \mathrm{x} 10(10) \mathrm{y}$. (i.e. more than three times longer than the current age of the universe; Kossert, 2003). Thus, there are two sources of ${ }^{87} \mathrm{Sr}$ in any material: primordial, formed during nucleosynthesis in stars (Watson et al., 2019) - along with ${ }^{84} \mathrm{Sr},{ }^{86} \mathrm{Sr}$ and ${ }^{88} \mathrm{Sr}$; and that formed by radioactive decay of ${ }^{87} \mathrm{Rb}$ (Davis et al., 1977; O'Nions, 1977; Kossert, 2003).

Strontium is released from the Earth's crust into the atmosphere as a result of natural processes such as entrainment of dust particles, resuspension of soil by wind, and sea spray. In addition, human activities, including milling and processing of strontium compounds, burning of coal, land application of phosphate fertilisers, and the usage of pyrotechnic devices, may cause strontium to be released into the atmosphere (Höllriegl \& München, 2011).

Strontium-isotopes are not directly indicative of climate but are rather reveal changes in process that could either cause or be the result of climate change. Strontium is commonly regarded as a proxy for the rate of chemical weathering of the continents and rate of seafloor spreading (Blum and Erel, 1995; Clow et al, 1997). Sr is well mixed in the oceans, so can provide a global signature of seawater chemistry (e.g. Stille, 1992; Chakrabarti et al., 1996). The Sr isotope ratio 
in seawater changes gradually over time, often showing no detectable variation over large time scales (Depaolo and Ingram, 1985; Clemens et al., 1993).

One of the key variables determining which processes (at which temporal resolution) can be traced by an elemental proxy like $\mathrm{Sr}$ in marine sediments is "residence time". Residence time is defined as the average time that a particle resides in a reservoir (Bolin and Henning, 1973). $\mathrm{Sr}$ in seawater is controlled by riverine discharge (Palmer and Edmond, 1992) or Sr flux from the upper mantle at Mid Ocean Ridges/hydrothermal vents (), and diagenesis and dissolution of deep-sea carbonates (Parrish 1998, pp. 25):

$$
\mathrm{N} d \mathrm{R}_{\mathrm{SW}} / d t=\mathrm{J}_{\mathrm{r}}\left(\mathrm{R}_{\mathrm{r}}-\mathrm{R}_{\mathrm{SW}}\right)+\mathrm{J}_{\mathrm{h}}\left(\mathrm{R}_{\mathrm{h}}-\mathrm{R}_{\mathrm{SW}}\right)+\mathrm{J}_{\mathrm{c}}\left(\mathrm{R}_{\mathrm{c}}-\mathrm{R}_{\mathrm{SW}}\right) .
$$

In the above equation, $\mathrm{N}$ is the number of moles of $\mathrm{Sr}$ in the ocean; $\mathrm{J}_{\mathrm{r}}, \mathrm{J}_{\mathrm{h}}, \mathrm{J}_{\mathrm{c}}$ are influxes of riverine hydrothermal and carbonate (either diagenesis or dissolution) $\mathrm{Sr}$ respectively; and $\mathrm{R}_{\mathrm{r}}$, $\mathrm{R}_{\mathrm{h}}, \mathrm{R}_{\mathrm{c}}, \mathrm{R}_{\text {.S.W. }}$ (Parrish 1998)

Assuming - and this may be a big if - that an element cycle is in a stable state and therefore the amount being introduced into the reservoir equals the amount leaving the reservoir is equal at any time, this residence time can be calculated easily via the following equations:

$$
\begin{aligned}
& \text { residence time }(\text { time })=\frac{\text { mass of element in reservoir }(\text { mass })}{\text { influx of element }(\text { mass per time })} \\
& \text { residence time }(\text { time })=\frac{\text { mass of element in reservoir }(\text { mass })}{\text { outflux of element }(\text { mass per time })}
\end{aligned}
$$

For strontium, one can calculate the residence time using equation 1 and employing an influx estimate of $4.04 * 10^{12} \mathrm{~g}$ per year (Pearce et al., 2015) and an oceanic reservoir size of $1.02 *$ $10^{19} \mathrm{~g}$ (de Viliers, 1999):

$$
\text { residence } \text { time }_{S r}=\frac{1.01 * 10^{19} \mathrm{~g} S r}{4.04 * 10^{12} \frac{g}{a} S r}=2.52 * 10^{6} a
$$

It follows that the average strontium ion remains dissolved in seawater for c. 2.5 million years before being precipitated in a carbonate mineral. 
The observation that modern carbonate shells have the homologous ${ }^{87} \mathrm{Sr} /{ }^{86} \mathrm{Sr}$ ratios across the globe (see Brand et al., 2003 for a modern example involving brachiopod data), makes strontium incredibly useful for global stratigraphic correlations as one can use the ${ }^{87} \mathrm{Sr} /{ }^{86} \mathrm{Sr}$ of marine carbonate, so long as the ratios have not been severally altered by diagenetic processes, as global stratigraphic marker.

Furthermore, the ${ }^{87} \mathrm{Sr} /{ }^{86} \mathrm{Sr}$ ratio of seawater changes slowly over geologic time spans as a consequence of global tectonic and climatic processes that caused significant changes in the balance of Sr fluxes from the continents and Mid Ocean Ridges. These changes are typically slow, but highly precise measurements allow for detecting small differences in the ${ }^{87} \mathrm{Sr} /{ }^{86} \mathrm{Sr}$ ratios of marine fossils through time represented by sedimentary sequences. Typically, one can hope for a time resolution of a few hundred thousand to a few million years. ${ }^{87} \mathrm{Sr} /{ }^{86} \mathrm{Sr}$ stratigraphy is therefore not highly precise but can be of enormous help when other - higher precision - tools for stratigraphic correlation do not work (Depaolo and Ingram, 1985).

It is worth stating, however, that ${ }^{87} \mathrm{Sr} /{ }^{86} \mathrm{Sr}$ is not an absolute dating technique but instead relies on a detailed knowledge about the strontium-isotope ratio of seawater at any given point in time (Peucker-Ehrenbrink and Fiske, 2019). To obtain such look-up chart that lists ${ }^{87} \mathrm{Sr} /{ }^{86} \mathrm{Sr}$ ratios throughout geological time, strontium-isotope measures have to be conducted for a large sample base of well-preserved fossils of known age. One such data set is the LOWESS 5 Fit, a collection of strontium isotope measurements dated every 0.05 million years (McArthur et al., 2012).

\section{Conclusion}

The purpose of this review was to provide a brief introduction to the application of stable isotopes in geochemistry. The stable isotopes of carbon, oxygen, and strontium have played an especially important role in furthering our understanding of past climates, biology, diets and stratigraphy.

- Some organisms make their bones, teeth, tests and shells in isotopic equilibrium with their environment.

- Oxygen is an important palaeothermometer used to reconstruct past ocean temperatures.

- Oxygen isotopes have been used, for example, to reconstruct dinosaur body temperatures and some that they were endothermic. 
- Carbon isotopes are primarily used as a proxy for changes in the global carbon cycles and have been instrumental in identifying Ocean Anoxic Events (e.g. the T-OAE)

- Carbon isotopes can be used to establish food webs.

- Strontium is a proxy for mid-ocean ridge/hydrothermal vent activity and can be used to date strata.

- Strontium is homologous in the oceans and ${ }^{87} \mathrm{Sr} /{ }^{86} \mathrm{Sr}$ ratios vary slowly over time, making them ideal for dating and correlating strata.

\section{References}

Anders, E. \& Ebihara, M. (1982). Solar-system abundances of the elements. Geochimica et Cosmochimica Acta 46(11): 2363-2380.

Amiot, R., Lécuyer, C., Buffetaut, E., Escarguel, G., Fluteau, F. \& Martineau, F. (2006). Oxygen isotopes from biogenic apatites suggest widespread endothermy in Cretaceous dinosaurs. Earth and Planetary Science Letters 246: 41-54.

Anderson, T F. \& Arthur M A. (1983). Stable isotopes of oxygen and carbon and their application to sedimentologic and paleaoenvironmental problems. In Arthur, M A., Anderson, T F., Kaplan, I R., Veizer, J., Land, L S (eds.). Stable Isotopes in Sedimentary Geology. SEPM Short Course \#10, Dallas, TX: Society of Economic Paleontologists and Mineralogists, pp.1-151.

Arkhipkin, A. I., Bizikov, V. A. \& Fuchs, D. (2012). Vestigial phragmocone in the gladius points to a Deepwater origin of squid (Mollusca: Cephalopoda). Deep-Sea Research 61: $109-122$.

Austin, W.E.N. \& James, R.H. (2008). Biogeochemical controls on palaeoceanographic environmental proxies. London: Geological Society, Special Publications 303.

Bailey, T.C., Rosenthal, Y., McArthur, J.M., van de Schootbrugge, B. * Thirlwall, M.F. (2003). Paleoceanographic changes of the Late Pliensbachian-Early Toarcian interval: a possible link to the genesis of an Oceanic Anoxic Event. Earth and Planetary Science Letters 212(3-4):307-320.

Banner, J. L. \& Hanson, G. N. (1990) Calculation of simultaneous isotopic and trace element variations during water-rock interaction with applications to carbonate diagenesis.

Geochimica et Cosmochimica Acta 54: 3123-3137.

Bartlett, R., Elrick, M., Wheeley, J.R., Polyak, V., Desrochers, A. \& Asmerom, Y. (2018). Abrupt global-ocean anoxia during the Late Ordovician-early Silurian detected using uranium isotopes of marine carbonates. Proceedings of the National Academy of Sciences 2018; 201802438 DOI: 10.1073/pnas.1802438115

Beerling, D. J., Lomas,M.R. \& Gröcke, D.R. (2002). On the nature of methane gas hydrate dissociation during the Toarcian and Aptian oceanic anoxic events. American Journal of Science 302(1): 28-49. 
Bigg, G. (2003). The oceans and climate. Cambridge: Cambridge University Press.

Blanchet, C.L., Kasten, S., Vidal, L., Poulton, S.W., Ganeshram, R. \& Thouveny, N. (2012). Influence of diagenesis on the stable isotopic composition of biogenic carbonates from the Gulf of Tehuantepec oxygen minimum zone. Geochemistry, Geophysics, Geosystems 13: Q04003, doi:10.1029/2011GC003800.

Blum, J. D. \& Y. Erel. (1995). A silicate weathering mechanism linking increases in marine ${ }^{87} \mathrm{Sr} /{ }^{86} \mathrm{Sr}$ with global glaciation, Nature 373: 415-418.

Bocherens, H., Fogel, M.L., Tuross, N. \& Zeder, M. (1995). Trophic structure and climatic information from isotopic signatures in Pleistocene cave fauna of southern England. Journal of Archaeological Science 22 (2): 327-340.

Bolin, B. \& Henning, R. (1973). A note on the concepts of age distribution and transit time in natural reservoirs. Tellus 25 (1): 58-62.

Brand, U., Logan, A., Hiller, N. \& Richardson, J. (2003). Geochemistry of modern brachiopods: applications and implications for oceanography and paleoceanography. Chemical Geology 198(3): 305-334.

Caruthers, A.H., Smith, P.L. \& Gröcke, D.R. (2013). The Pliensbachian-Toarcian (Early Jurassic) extinction, a global multi-phased event. Palaeogeography, Palaeoclimatology, Palaeoecology 386: 104-118

Catling, D.C. \& Kasting, J. F. (2017). Atmospheric evolution on inhabited and lifeless worlds. Cambridge: Cambridge University Press.

Cerling, T. E., Harrism J. M., MacFaddenm B. J., Leakey, M. G., Quade, J., Eisenmann, V. \& Ehleringer, J. R. (1997). Global vegetation change through the Miocene/Pliocene boundary. Nature 389: 153-158.

Chakrabarti, R., Mondal, S., Acharya, S. S., Lekha, J. S. \& Sengupta, D. (2018). Submarine groundwater discharge derived strontium from the Bengal Basin traced in Bay of Bengal water samples. Scientific reports 8(1), 4383. doi.org/10.1038/s41598-018-22299-5.

Clemens, S. C., Farrell, J.W. \& Gromet, L. P. (1993). Synchronous changes in seawater strontium isotope composition and global climate. Nature 363: 607-610.

Clementz, M.T. (2012). New insight from old bones: stable isotope analysis of fossil mammals. Journal of Mammalogy 93 (2): 368-380.

Clow, D. W., Mast, M.A., Bullen, T.D. \& Turk, J.T. (1997). Strontium 87/strontium 86 as a tracer of mineral weathering reactions and calcium sources in an alpine/subalpine watershed, Loch Vale, Colorado. Water resources research 33 (6): 1335-1351.

Cohen, A.S., Coe, A.L., Harding, S.M. \& Schwark, L. (2004). Osmium isotope evidence for the regulation of atmospheric CO2 by continental weathering. Geology 32(2): 157-160. 
Davis, D.W., Gray, J., Gumming, G.I. \& Baadsgaard, H. (1977). Determination of the ${ }^{87} \mathrm{Rb}$ decay constant. Geochimica et Cosmochimica Acta 41 (12): 1745-1749.

De Villiers, S. (1999). Seawater strontium and $\mathrm{Sr} / \mathrm{Ca}$ variability in the Atlantic and Pacific oceans. Earth and Planetary Science Letters 171(4): 623-634.

Deines, P. (1980). The isotopic composition of reduced organic carbon. In P. Fritz. \& J. Fontes (eds). Handbook of environmental isotope geochemistry. Amsterdam: Elsevier, pp. 239-406.

DeNiro, M.J. \& Epstein, S. (1978). Influence of diet on the distribution of carbon isotopes in animals. Geochimica et Cosmochimica Acta 42 (5): 495-506.

Depaolo, D.J. \& Ingram, B.L. (1985). High-resolution stratigraphy with strontium isotopes. Science 227(4689): 938-941.

Donovan, D. T. (1977). Evolution of the dibranchiate cephalopoda. Symposium of the Zoological Society, London 38: 15-48.

Ellam, R. (2016). Isotopes: a very short introduction. Oxford: Oxford University Press.

Elling, F. J., Gottschalk, J., Doeana, K.D., Kusch, S., Hurley, S. J. \& Pearson, A. (2019). Archaeal lipid biomarker constraints on the Paleocene-Eocene carbon isotope excursion. Nature Communications 10(4519): doi:10.1038/s41467-019-12553-3.]

Epstein, S. \& Mayeda, T. (1953). Variation of $\mathrm{O}^{18}$ content of waters from natural sources. Geochimica et Cosmochimica Acta 4(5): 213-224.

Erba, E., Bottini, C., Weissert, H.J. \& Keller, C.E. (2010).Calcareous nannoplankton response to surface-water acidification around Oceanic Anoxic Event 1a. Science 329(5990): 428-432.

Farmer, G. \& Baxer, M.S. (1976). Atmospheric carbon dioxide records levels as indicated by the stable isotope record in wood. Nature 247: 273-275.

Faure, G. \& Mensing, T. M. (2005). Isotopes: principles and applications. London: Wiley.

Foster, G. L. \& Rae, J. W.B. (2016). Reconstructing ocean $\mathrm{pH}$ with boron isotopes in foraminifera. Annual Review of Earth and Planetary Sciences 44 (1): 207-237.

Fujioka, H., Takayanagi, H., Yamamoto, K., Iryu, Y. (2019). The effects of meteoric diagenesis on the geochemical composition and microstructure of Pliocene fossil Terebratalia coreanica and Laqueus rubellus brachiopod shells from northeastern Japan. Progress in Earth and Planetary Science 6(45): doi.org/10.1186/s40645-019-0289-7.

Gat, J. R. (1996). Oxygen and hydrogen isotopes in the hydrological cycle. Annual Review of Earth and Planetary Sciences 24: 225-262. 
Hakenbeck, S., McManus, E., Geisler, H., Grupe, G. \& O'Connell, T. (2010). Diet and Mobility in Early Medieval Bavaria: A Study of Carbon and Nitrogen Stable Isotopes. American Journal of Physical Anthropology 143 (2): 235-249.

Hansen, J., Sato, M., Ruedy, R., Lo, K., Lea, D.W. \& Medina-Elizade, M. (2006). Global temperature change. PNAS 103(39): 14288-14293.

Harries, P.J. \& Little, C.T. (1999). The early Toarcian (Early Jurassic) and the CenomanianTuronian (Late Cretaceous) mass extinctions: similarities and contrasts. Palaeogeography, Palaeoclimatology, Palaeoecology 154(1-2): 39-66.

Hazen, R.M. (2018). Carbon in Earth (Reviews in Mineralogy \& Geochemistry \# 75). Berlin: De Gruyter.

Hendricks, M. B., Depaolo, D. J. \& Cohen, R. C.(2000). Space and time variation of $\delta^{18} \mathrm{O}$ and $\delta \mathrm{D}$ in precipitation: can paleotemperature be estimated from ice cores? Global biogeochemical cycles 14 (3): 851-861.

Hesselbo, S.P., Gröcke, D.R., Jenkyns, H.C., Bjerrum, C.J., Farrimond, P., Bell, H.S.M. \& Green, O.R. (2000). Massive dissociation of gas hydrate during the Jurassic oceanic anoxic event. Nature 406: 392-395.

Hesselbo, S.P., Jenkyns, H.C., Duarte, L.V. \& Oliveira, L.C.V. (2007). Carbon-isotope record of the Early Jurassic (Toarcian) Oceanic Anoxic Event from fossil wood and marine carbonate (Lusitanian Basin, Portugal). Earth and Planetary Science Letters 253: 455-470.

Höllriegl, V. \& München, H. Z. (2011). Strontium in the environment and possible human health effects. In J.O. Nriagu (ed.). Encyclopaedia of Environmental Health. Amsterdam: Elsevier, pp. 268-275.

Holtz, T.R. (2008). A critical reappraisal of the obligate scavenging hypothesis for Tyrannosaurus rex and other giant dinosaurs. In P. Larson. \& K. Carpenter (eds.). Tyrannosaurus rex: the tyrant king. Bloomington: Indiana University Press, pp. 371-398.

Hopkins III, J.B. \& Ferguson, J.M. (2012). Estimating the diets of animals using stable isotopes and a comprehensive Bayesian Mixing Model. PLoS ONE 7(1): e28478.

Hudson, J.D. \& Marshall, J.D. (1997). Isotope studies in palaeontology. Journal of the Geological Society 154 (2): 283.

Jagoutz, E., Palme, H., Baddenhausen, H., Blum, K., Cendales, M., Dreibus, G., Spettel, B., Wänke, H. \& Lorenz, V. (1979). The abundances of major, minor and trace elements in the Earth's mantle as derived from primitive ultramafic nodules. Lunar and Planetary Science Conference Proceedings 10: 2031-2050.

Jeletzky, J. A. (1966). Comparative morphology, phylogeny, and classification of fossil coleoidea. The University of Kansas Paleontological Contributions, Mollusca Article 7. Lawrence: University of Kansas Paleontological Institute, pp 1-162. 
Jenkyns, H. C. \& Clayton, C.J. (1986). Black shales and carbon isotopes in pelagic sediments from the Tethyan Lower Jurassic. Sedimentology 33: 87-106.

Jenkyns, H.C. (1988). The early Toarcian (Jurassic) anoxic event-stratigraphic, sedimentary, and geochemical evidence. American Journal of Science 288(2):101-151.

Jiang, M., Zhu, J., Chen, D., Zhang, R. \& Qiao, G. (2001). Carbon and strontium isotope variations and responses to sea-level fluctuations in the Ordovician of the Tarim Basin. Science in China Series D: Earth Sciences 44(816): DOI: 10.1007/BF02907094.

Jones, C. E., Jenkyns, H. C., Coe, A. J. \& Hesselbo, S. P. (1994). Strontium isotopic variations in Jurassic and Cretaceous seawater. Geochimica et Cosmochimica Acta 58 (14): 3061-3074.

Kaiho, K., Chen, Z.Q. \& Sawada, K. (2009). Possible causes for a negative shift in the stable carbon isotope ratio before, during and after the end-Permian mass extinction in Meishan, South China. Australian Journal of Earth Sciences 56:799-808.

Knauth, L. \& Kennedy, M. (2009). The late Precambrian greening of the Earth. Nature 460: 728-732.

Kossert, K. (2003). Half-life measurements of $87 \mathrm{Rb}$ by liquid scintillation counting. Applied Radiation and Isotopes 59(5-6):377-382.

Lamb, A.L., Evens, J.E., Buckley, R. \& Appleby, J. (2014). Multi-isotope analysis demonstrates significant lifestyle changes in King Richard III. Journal of Archaeological Science 50: 559-565.

Lohmann, G. P. (2006). A model for variation in the chemistry of planktonic foraminifera due to secondary calcification and selective dissolution. Paleoceanography 10: 445-458.

Lowenstam, H.A. \& Epstein, S. (1954). Paleotemperatures of the Post-Aptian Cretaceous as Determined by the Oxygen Isotope Method. The Journal of Geology 62(3): 207-248.

Marshall, J.D. (1992). Climatic and oceanographic isotopic signals from the carbonate rock record and their preservation: Geological Magazine 192:143-160.

McArthur, J.M., Howarth, R. J. \& Shields, G.A. (2012). Strontium isotope stratigraphy. In: F.M. Gradstein., J.G. Ogg., M.D. Schmitz. \& G.M. Ogg (eds.). A Geologic Time Scale (Vol 1) Amsterdam: Elsevier, pp 127-144.

McArthur, J.M., Algeo, T.J., van de Schootbrugge, B., Li, Q. \& Howarth, R.J. (2008). Basinal restriction, black shales, Re-Os dating, and the Early Toarcian (Jurassic) oceanic anoxic event Paleoceanography 23(4): PA4217.

Nier, A.O. (1938). The isotopic constitution of strontium, barium, bismuth, thallium and mercury. Physical Review 54(4): 275.

Norris, R.D., Turner, S.K., Hull, P.M. \& Ridgwell, A. (2013). Marine ecosystem responses to Cenozoic global change. Science 341:492-498.

O'Leary. M.H. (1988). Carbon isotopes in photosynthesis. Bio Science 38: 328-336. 
O'Nions, R.K., Hamilton, P.J. \& Evensen, N. M. (1977). Variations in ${ }^{143} \mathrm{Nd} /{ }^{144} \mathrm{Nd}$ and ${ }^{87} \mathrm{Sr} /{ }^{86} \mathrm{Sr}$ ratios in oceanic basalts. Earth and Planetary Science Letters 34: 13-22.

Owens, J.D. \& Them II, T.R. (2018). Volcanic eruptions once caused mass extinctions in the oceans - could climate change do the same? The Conversation. Available: https://theconversation.com/volcanic-eruptions-once-caused-mass-extinctions-in-the-oceanscould-climate-change-do-the-same-99655.

Owocki, K., Kremer, B., Cotte. \& Bocherens, H. (2019). Diet preferences and climate inferred from oxygen and carbon isotopes of tooth enamel of Tarbosaurus bataar (Nemegt Formation, Upper Cretaceous, Mongolia). Palaeogeography, Palaeoclimatology, Palaeoecology 537: 109-190.

Palmer, M.R. \& Edmond, J.M. (1992). Controls over the strontium isotope composition of river water. Geochimica et Cosmochimica Acta 56(5): 2099-2111.

Pandolfi, J.M., Connolly, S.R., Mrashall, D.J. \& Cohen, A.L. (2011). Projecting coral reef futures under global warming and ocean acidification. Science 333(6041):418-422.

Parng, E., Crumpacker, A. \& Kurle, C.M. (2014). Variation in the stable carbon and nitrogen isotope discrimination factors from diet to fur in four felid species held on different diets. Journal of Mammalogy 95(1): 151-159.

Parrish, J.T. (1998). Interpreting pre-Quaternary climate from the geologic record. New York: Columbia University Press.

Pearce, C.R., Parkinson, I.J., Gaillardet, J., Charlier, B.L., Mokadem, F. \& Burton, K.W. (2015). Reassessing the stable $\left(\delta^{88 / 86} \mathrm{Sr}\right)$ and radiogenic $\left({ }^{87} \mathrm{Sr} /{ }^{86} \mathrm{Sr}\right)$ strontium isotopic composition of marine inputs. Geochimica et Cosmochimica Acta 157: 125-146.

Pederzani, S., \& Britton, K. (2018). Oxygen isotopes in bioarchaeology: Principles and applications, challenges and opportunities. Earth Science Reviews. doi:10.1016/j.earscirev.2018.11.005.

Peucker-Ehrenbrink, B. \& Fiske, G.J. (2019). A continental perspective of the seawater ${ }^{87} \mathrm{Sr} /{ }^{86} \mathrm{Sr}$ record: A review. Chemical Geology 510: 140-165.

Podlaha, O., Mutterlose, J \& Veizer, J. (1998). Preservation of delta O-18 and delta C-13 in belemnite rostra from the Jurassic Early Cretaceous successions. American Journal of Science 298: 324-347.

Post, D. M. (2002). Using stable isotopes to estimate trophic position: models, methods, and assumptions. Ecology 83(3): 703-718.

Prince, G.D. \& Sellwood, B.W. (1997). "Warm" palaeotemperatures from high Late Jurassic palaeolatitudes (Falkland Plateau): Ecological, environmental or diagenetic controls? Palaeogeography, Palaeoclimatology, Palaeoecology 129(3-4): 315-327. 
Ravelo, A. C. \& Hillaire-Marcel, C. (2007). The use of oxygen and carbon isotopes of foraminifera in paleoceanography. In. C. Hillaire-Marcel. \& A. De Vernal (eds). Developments in marine geology, volume 1. Amsterdam: Elsevier, pp. 735-764.

Rexfort, A. \& Mutterlose, J. (2006). Stable isotope record from Sepia officinalis - a key to understanding the ecology of belemnites? Earth and Planetary Science Letters 247 (2006): 212-221.

Rexfort, A. \& Mutterlose, J. (2009). The role of biogeography and ecology on the isotope signature of cuttlefishes (Cephalopoda, Sepiidae) and the impact on belemnite studies. Palaeogeography, Palaeoclimatology, Palaeoecology 284: 153-163.

Robin, G.Q. (1977). Ice cores and climate change. Philosophical transactions of the Royal Society B280 (972): 143-168.

Rutherford, E. \& Soddy, F. (1902). The cause and nature of radioactivity, part 1. Philosophical Magazine 4: 370-396.

Sælen, G. (1989). Diagenesis and construction of the belemnite rostrum. Palaeontology 32: 765-798.

Sælen, G., Doyle, P. \& Talbot, M. (1996). Stable-Isotope Analyses of Belemnite Rostra from the Whitby Mudstone Fm., England: Surface Water Conditions during Deposition of a Marine Black Shale. Palaios 11(2): 97-117.

Schoeller, D. A. (1999). Isotope fractionation: why aren't we what we eat? Journal of Archaeological Science 26 (6): 667-673.

Schouten, S., van Kaam-Peters, H. M. E., Rijpstra, W. I. C., Schoell, M. \& Damste, S. (2000), Effects of an oceanic anoxic event on the stable carbon isotopic composition of early Toarcian carbon. American Journal of Science 300: 1-22.

Shackleton, N., Hall, M., Line, J. \& Shuxi, C. (1983). Carbon isotope data in core V19-30 confirm reduced carbon dioxide concentration in the ice age atmosphere. Nature 306: 319-322.

Shackleton, N.J. \& Kennett, J.P. (1975). Paleotemperature history of the Cenozoic and initiation of Antarctic glaciation: oxygen and carbon isotope analyses in DSDP sites 277, 279 and 289. Initial Reports of the Deep Sea Drilling Project 29: 743-755.

Sharp, Z. (2007) Principles of stable isotope geochemistry. New Jersey: Pearson Education

Showers, W.J., Barrick, R. \& Genna, B. (2002). Isotopic analysis of dinosaur bones: A new pyrolysis technique provides direct evidence that some dinosaurs were warm-blooded. Analytical Chemistry 74: 142-150.

Siegenthaler, U., Friedli, H., Loetscher, H., Moor, E., Neftel, A., Oeschger, H. \& Stauffer, B. (1988). Stable-isotope ratios and concentration of $\mathrm{CO}_{2}$ in air from polar ice cores. Annals of glaciology 10: 151-156.

Soddy, F. (1913). The radio-elements and the periodic law. Chemical news 107: 97-99. 
Stanley, S.M. (2010). Relation of Phanerozoic stable isotope excursions to climate, bacterial metabolism, and major extinctions. PNAS 107(45): 19185-19189.

Stevens, G.R. \& Clayton, R.N. (1971). Oxygen isotope studies on Jurassic and Cretaceous belemnites from New Zealand and their biogeographic significance. New Zealand Journal of Geology and Geophysics 14(4): 829-897.

Stille. P. (1992). Nd-Sr isotope evidence for dramatic changes of paleo-currents in the Atlantic Ocean during the past 80 million years. Geology 20: 387-390.

Suess, H.E. (1955). Radiocarbon concentrations in modern wood. Science 122:415-417.

Them II, T.R., Gill, B.C., Gröcke, D.R., Friedman, R.M. \& Owens, J.D. (2017). Evidence for rapid weathering response to climatic warming during the Toarcian Oceanic Anoxic Event. Scientific Reports 7 (5003): DOI:10.1038/s41598-017-05307-y.

Thomas. C.D., Cameron, A., Green, R.E., Bakkenes, M., Beaumont, L. J., Collingham, Y.C., Erasmus, B. F. N., de Siqueira, M. F., Grainger, A., Hannah, L., Hughes, L., Hunter, B., van Jaarsveld, A.S., Midgley, G. F., Miles, L., Ortega-Huerta, M.A., Peterson, A.T., Philips, O.L. $\&$ Williams, S.E. (2004). Extinction risk from climate change. Nature 427:145-148.

Thomson, J. J. (1910). LXXXIII. Rays of positive electricity. Philosophical Magazine 20 (118): 752-767.

Thomson, J. J. (1912). XIX. Further experiments on positive rays. Philosophical Magazine 24 (140): 209-253.

Tourtelot, H.A. \& Rye, R.O. (1969). Distribution of oxygen and carbon isotopes in fossils of Late Cretaceous age, Western Interior region of North America. G.S.A. Bulletin 80(10): 19031922.

Ullmann, C.V., Korte, C. (2015). Diagenetic alteration in low-Mg calcite from macrofossils: a review. Geological Quarterly 59(1):3-20.

Urey, H.C. (1947). The thermodynamic properties of isotopic substances. Journal of the Chemical Society 1947: 562-581.

Urey, H.C., Lowenstam, H.A., McKinney, C.R (1951). Measurement of paleotemperatures and temperatures of the Upper Cretaceous of England, Denmark, and the southeastern UnitedStates. Geological Society of America Bulletin 62: 399-416.

van der Meer, D.G., van den Berg van Saparoea, A.P.H., van Hinsbergen, van de Weg, R.M.B., Godderis Y., Le Hir, G. \& Donnadieu, Y. (2017). Reconstructing first-order changes in sea level during the Phanerozoic and Neoproterozoic using strontium isotopes. Gondwana Research 44: 22-34.

Vervoort, P., Adloff, M., Greene, S.E., Kirtland Turner, S. (2019). Negative carbon isotope excursions: an interpretive framework. Environmental Research Letters 14 (8): 085014 
Wallace, D.R. (2004). Beasts of Eden: walking whales, dawn horses, and other enigmas of mammal evolution. Berkley: University of California Press.

Watson, D., Hasen, C.J., Selsing, J., Koch, A., Malesani, D. B., Anderson, A.C., Fynbo, J. P. U., Arcomes, A., Bauswein, A., Covino, S., Grado, A., Heintz, K.E., Hunt, L., Kouvelioyou, C., Lelpudas, G., Levan, A. J., Mazzali, P. \& Pian, E. (2019). Identification of strontium in the merger of two neutron stars. Nature 574 (6325): 497-500.

Webb, E., White, C. \& Longstaffe, F. (2013). Dietary shifting in the Nasca Region as inferred from the carbon- and nitrogen-isotope compositions of archaeological hair and bone. Journal of Archaeologial Science 40 (1): 129-139.

Wefer, G. \& Berger, W. H. (1991). Isotope paleontology: growth and composition of extant calcareous species. Marine Geology 100 (1-4): 207-248.

Wernerm M., Jouzel, J., Masson-Delmotte, V. \& Lohmann, G. (2018). Reconciling glacial Antarctic water stable isotopes with ice sheet topography and the isotopic paleothermometer. Nature Communications 9(3537): doi.org/10.1038/s41467-018-05430-y.

Wierzbowski, H. \& Joachimiski, M.M. (2007). Reconstruction of te Bajocian-Bathonian marine palaeoenvironments using carbon and oxygen isotope ratios of calcareous fossils from the Polish Jura Chain (central Poland). Palaeogeography, Palaeoclimatology, Palaeoecology 254: $523-540$.

Wierzbowski, H. \& Joachimiski, M.M. (2009). Stable isotopes, elemental distribution, and growth rings of belemnopsid belemnite rostra: proxies for belemnite life habitat. Palaios 24(56): 377-386.

Wignall, P.B., Newton, R.J. \& Little, C.T. (2005). The timing of paleoenvironmental change and cause-and-effect relationships during the Early Jurassic mass extinction in Europe. American Journal of Science 305(10): 1014-1032.

Wilkin, J.T.R. (2020). Calculating ancient temperatures using oxygen. Research Outreach. Available: https://researchoutreach.org/community-content/calculating-ancient-temperaturesusing-oxygen/.

Wilmsen, M. \& Niebuhr, B. (2017). High-resolution Campanian-Maastrichtian carbon and oxygen stable isotopes of bulk-rock and skeletal components: palaeoceanographic and palaeoenvironmental implications for the Boreal shelf sea. Acta Geologica Polonica 67(1): 4774.

Wings, O., Tütken, T., Fowler, D., Martin, T., Pfretzschner, H.-U. \& Sun, G. (2014). Dinosaur teeth from the Jurassic Qigu and Shishugou Formations of the Junggar Basin (Xinjiang/China) and their paleoecologic implications. Paläontologische Zeitschrift 89: 485-502.

Xu, W., Ruhl, M., Jenkyns, H.C., Leng, M.J., Huggett, J.M., Minisini, D., Ullmann, C.V., Riding, J.B., Weijers, J.W.H., Storm, M.S., Percival, L.M.E., Tosca, N.J., Idiz, E.F., Tegelaar, E.W. \& Hesselbo, S.P. (2018). Evolution of the Toarcian (Early Jurassic) carbon-cycle and global climatic controls on local sedimentary processes (Cardigan Bay Basin, UK). Earth and Planetary Science Letters 484: 396-411. 
Yurtsever, Y., 1975. Worldwide survey of stable isotopes in precipitation. International Atomic Energy Agency. Isotope Hydrology Section: IAEA.

Zondervan, I., Zeebe, R.E., Rost, B. \& Riebesell, U. (2001). Decreasing marine biogenic calcification: A negative feedback on rising atmospheric $\mathrm{pCO}_{2}$. Global Biochemical Cycles 15(2):507-516. 